\title{
Isolated and prolonged loss of time orientation
}

Figure $1 \quad$ Brain images

A
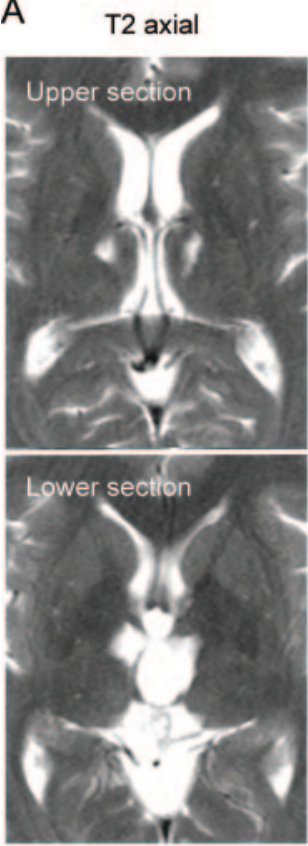

T1 sagittal
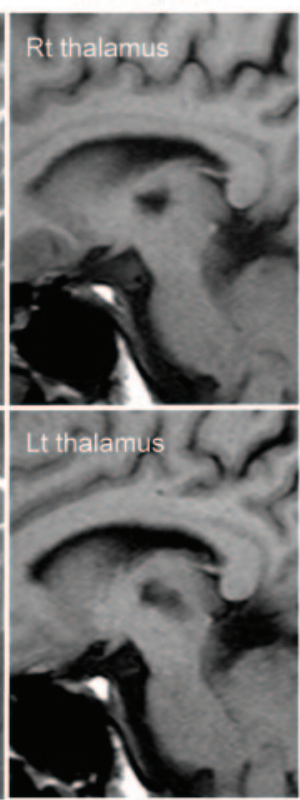

B

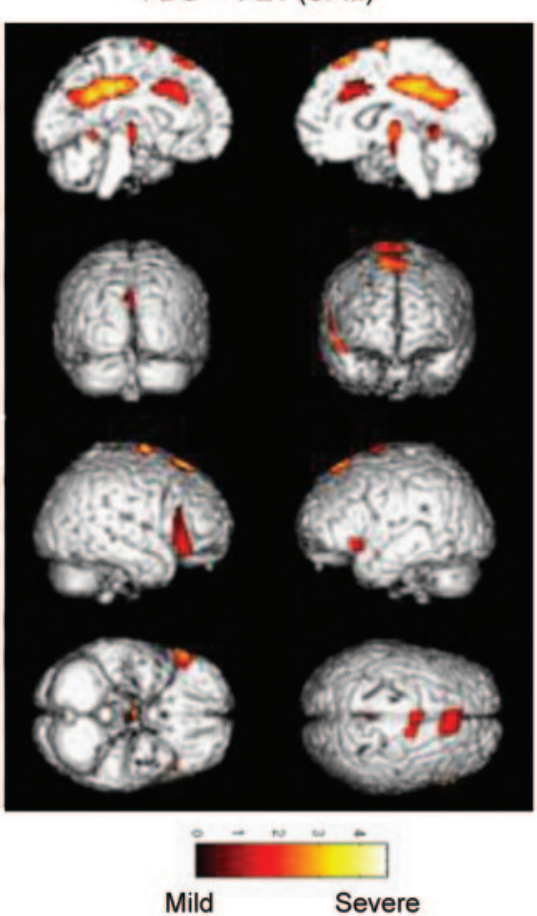

C
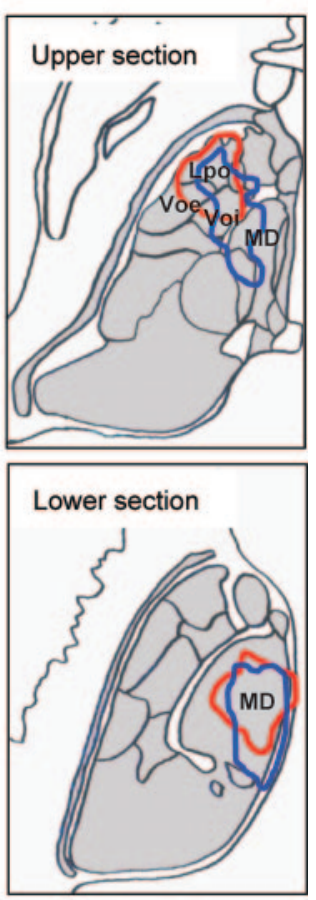

Rt lesion

Lt lesion

MRI shows medial thalamic lesions (A). Statistical parametric map (SPM) of FDG-PET revealed hypometabolism in the cingulate cortex, especially in the posterior part (B). The core lesions were merged in the mediodorsal nucleus (C). $\mathrm{Lpo}=$ lateropolaris; $\mathrm{MD}=$ mediodorsal; Voe $=$ ventro-oralis externus; $\mathrm{Voi}=$ ventro-oralis intermedius.

Supplemental data at www.neurology.org
In 1996, a 33-year-old man was admitted for a sudden somnolence, and was diagnosed with bilateral medial thalamic infarction (figure 1). Although his consciousness returned after a week, he presented a severe isolated impairment of time orientation, which has continued for more than 13 years. His episodic memories after the stroke were registered without time information (see appendix e-1 and figure e-1 on the Neurology ${ }^{\circledR}$ Web site at www.neurology.org). The bilateral thalamic MRI lesions merged in the mediodorsal nucleus, ${ }^{1}$ and FDG-PET in 2004 showed severe hypometabolism in the posterior cingulate cortex and milder hypometabolism in the anterior cingulate. This case suggests that thalamic projection to the cingulate ${ }^{2}$ participates in the processing of time information.

\section{Soon-Tae Lee, MD, Kon Chu, MD, PhD, Manho Kim, MD, PhD, Jae-Kyu Roh, MD, PhD, Seoul, South Korea}

Disclosure: Dr. Lee, Dr. Chu, and Dr. Kim report no disclosures. Dr. Roh serves as an Associate Editor for Laboratory Investigation and the Journal of Alzheimer's Disease.

Author contributions: Statistical analysis was conducted by Dr. Soon-Tae Lee.

Address correspondence and reprint requests to Dr. Jae-Kyu Roh, Department of Neurology, Seoul National University Hospital, 101, Daehangno, Jongno-Gu, Seoul, 110-744, South Korea; rohjk@snu.ac.kr

1. von Cramon DY, Hebel N, Schuri U. A contribution to the anatomical basis of thalamic amnesia. Brain 1985;108:993-1008.

2. Vogt BA, Rosene DL, Pandya DN. Thalamic and cortical afferents differentiate anterior from posterior cingulate cortex in the monkey. Science 1979;204:205-207. 


\title{
Neurology
}

\author{
Isolated and prolonged loss of time orientation \\ Soon-Tae Lee, Kon Chu, Manho Kim, et al. \\ Neurology 2010;75;1120 \\ DOI 10.1212/WNL.0b013e3181f39d21
}

This information is current as of September 20, 2010

\section{Updated Information \& Services}

\section{Supplementary Material}

\section{References}

Citations

Subspecialty Collections

Permissions \& Licensing

Reprints including high resolution figures, can be found at: http://n.neurology.org/content/75/12/1120.full

Supplementary material can be found at: http://n.neurology.org/content/suppl/2010/09/19/75.12.1120.DC1

This article cites 2 articles, 1 of which you can access for free at: http://n.neurology.org/content/75/12/1120.full\#ref-list-1

This article has been cited by 1 HighWire-hosted articles: http://n.neurology.org/content/75/12/1120.full\#\#otherarticles

This article, along with others on similar topics, appears in the following collection(s):

All Cognitive Disorders/Dementia

http://n.neurology.org/cgi/collection/all_cognitive_disorders_dementia All Neuropsychology/Behavior

http://n.neurology.org/cgi/collection/all_neuropsychology_behavior

\section{Infarction}

http://n.neurology.org/cgi/collection/infarction

\section{Memory}

http://n.neurology.org/cgi/collection/memory

PET

http://n.neurology.org/cgi/collection/pet

Information about reproducing this article in parts (figures,tables) or in its entirety can be found online at:

http://www.neurology.org/about/about_the_journal\#permissions

Information about ordering reprints can be found online:

http://n.neurology.org/subscribers/advertise

Neurology ${ }^{\circledR}$ is the official journal of the American Academy of Neurology. Published continuously since 1951, it is now a weekly with 48 issues per year. Copyright . All rights reserved. Print ISSN: 0028-3878. Online ISSN: 1526-632X.

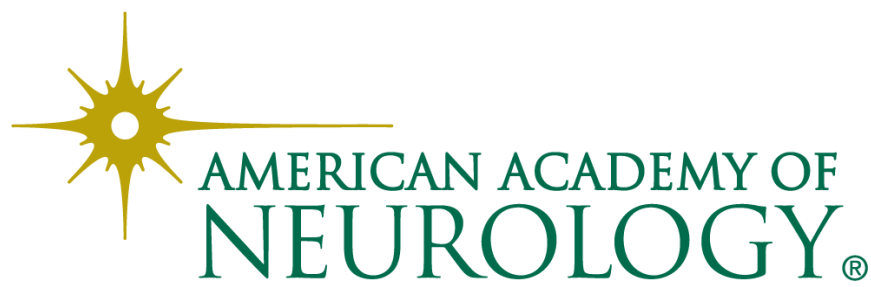

